\title{
The Effect of Non-Audit Services on Auditor Independence: Evidence from Vietnam
}

\author{
Nga Thanh DOAN ${ }^{1}$, Cuong Duc PHAM${ }^{2}$, Thuong Thi Uyen NGUYEN ${ }^{3}$, Mai Phuong VU ${ }^{4}$, Lam Ha PHAM
}

Received: September 01, 2020 Revised: October 26, 2020 Accepted: November 05, 2020

\begin{abstract}
Independence is a factor which has a significant impact on auditing quality, especially in the recent times where the marketplace is increasingly demanding transparency. The independence of auditors is assessed based on the main criteria such as the reliability of the audit opinions, the accuracy, truthfulness of financial reports, and the objectivity in the opinions of the auditor. The study investigates the effects of non-audit services (NAS) on auditor independence in emerging economies such as Vietnam. Non-audit services include taxation services, management advisory services and outsourcing internal audit services. Based on previously relevant researches, the authors develop hypotheses and a regression model about non-audit services (independent variables) and audit independence (dependent variable). The research collects data by 5 -scale Likert questionnaire. The findings indicate the relationship between NAS and auditor independence. Specifically, the results reveal two main factors that have influence on auditor independence, namely, taxation services and management advisory services. The results of our research can be considered as new findings and can be compared to previous researches in Vietnam, which establishes a new viewpoint about the relationship between the NAS and the independence of the auditor. This result can be implemented for countries or jurisdictions which are similar to Vietnam.
\end{abstract}

Keywords: Audit, Auditor Independence, Non-audit Services

JEL Classification Code: M40, M42, M48

\section{Introduction}

Independence is a factor which has a significant impact on auditing quality, especially in the recent times where the marketplace is increasingly demanding transparency.

${ }^{1}$ First Author. Lecturer, Auditing Department, School of Accounting and Auditing, National Economics University, Vietnam.

Email: doanthanhnga@neu.edu.vn

${ }^{2}$ Corresponding Author. Associate Professor, Head of Accounting Principles Department, School of Accounting and Auditing, National Economics University, Vietnam [Postal Address: 207 Giai Phong, Hai Ba Trung, Hanoi, 113068, Vietnam] Tel: +84 972346699.

Email: cuongpd@neu.edu.vn

${ }^{3}$ School of Accounting and Auditing, National Economics University, Vietnam

${ }^{4}$ School of Accounting and Auditing, National Economics University, Vietnam

${ }^{5}$ School of Accounting and Auditing, National Economics University, Vietnam

(C) Copyright: The Author(s)

This is an Open Access article distributed under the terms of the Creative Commons Attribution Non-Commercial License (https://creativecommons.org/licenses/by-nc/4.0/) which permits unrestricted non-commercial use, distribution, and reproduction in any medium, provided the original work is properly cited.
Moreover, independence is not the only essential condition for a company to achieve certain aims in auditing but also a critical principle to auditors. NAS, together with independence, is a considerable cause of concern these days. Under the pressure of brand reputation and profit making for administration, many audit firms recently provide NAS in addition to their audit services, such as management advisory services, information system services, taxation services. Changes in the proportion of audit firms' services give rise to a problem relating to the provision of NAS and whether it affects auditor independence. In order to clarify this issue, various researches investigating the relationship between NAS and auditor independence have been undertaken, including those by Blay and Geiger (2013) in the United States, Ratzinger-Sakel (2013) for Germany, and Habib and Islam (2007), who chose Bangladesh to prove their hypothesis.

In Vietnam, regulations on the independence of the auditor are given in legal documents. However, the influence of providing NAS on auditor independence is still one of the most concerning subjects, due to its far-reaching impact on many business entities and state agencies' operation. 
Therefore, researches about this influence are absolutely necessary in the economic context of Vietnam.

In this paper, the authors will concentrate on analysing particular factors so as to evaluate the effect of providing NAS on auditor independence in Vietnam's recent years' economy.

\section{Literature Review and Hypotheses}

\subsection{Auditor Independence}

Bartlett (1993) conducted a research about auditor independence and defined independence as an unbiased mental attitude in making decisions about audit word and financial reporting. Hence, independence in audit work could be understood as the auditor neither affected nor manipulated by any mental or physical benefits which cause dishonesty and subjectiveness.

The U.S. Securities and Exchange Commission (SEC) defined independence as a mental state of objectivity and lack of bias. Since independence refers to a mental state, which is invisible, the SEC considered that an auditor is not independent if a reasonable investor, with knowledge of all relevant facts and circumstances, would conclude that the auditor is not capable of exercising objective and impartial judgement (SEC, 2000).

In the Code of Professional Conduct, the American Institute of Certified Public Accountants required auditors to maintain independence both in fact and appearance when performing auditing and attestation services (AICPA, 1997a). AICPA (1997b) defines independence as the auditor must not be biased by any benefits that lead to unacceptable mistakes in audit quality or information context of an audit arrangement.

According to Beattie, Brandt and Fearnley (1999), independence was considered as a fundamental characteristic of an auditor. They assumed auditor independence was a part of the capital market's nature and related firmly to the efficiency of capital used in the market.

Otherwise, Dopuch, King, and Schwartz (2003) considered two types of independence: Independence in fact and independence in appearance. Independence in fact is that the auditor must maintain an independent mind when planning and providing audit services. Independence in appearance is how a third-party perceives whether the auditor has no joint relation with the customers. Similarly, independence is categorized into two types according to the International Federation of Accountants (IFAC), independence in fact and independence in appearance.

\subsection{Non-Audit Services}

Firth (1997) defined management advisory services (nonaudit services) as "the hiring of an outside firm (or individual) that makes recommendations to a company's executives and /or is charged with the task of planning and implementing some course of action for corporate management". Even though a company could hire a skilled individual to perform these services, management advisory services could be done by internal employees, Firth (1997) emphasized.

According to Financial Reporting Council (FRC), nonaudit services "comprise any engagement in which an audit firm provides professional services to an audited entity, an audited entity's affiliates or another entity in respect of the audited entity other than the audit of financial statements of the audited entity" (FRC, 2010).

The research of Brandon, Crabtree, and Maher (2004) showed non-audit fees as "all fees not directly charged to the audit, including systems implementation, systems modification, tax preparation, consultation and internal audit fees".

In the book titled "Auditing and assurance services", Eilifsen, Messier, Glover and Prawitt (2013) clearly outlined some of NAS (consultancy services) provided by auditors and how these services had been considered as moves that weaken their independence. According to them, during the economic boom in the 1990s and 2000s, most audit firms generated high revenue by providing consultancy services. Many researchers discovered that auditors helped management enhance the boundaries of accounting standards because of their provision of NAS to these companies (Frankel, Johnson \& Nelson, 2002; Simunic, 1984; Firth, 1997; Kwak and Park, 2020). Auditors are afraid of losing some of their rent (fees) due to management activities. Thus, auditors' objectivity is examined in case they depend on customers.

Law (2010) indicated four common non-audit services which audit firms mostly provided to their customers. These services, namely, taxation services, internal audit services, accounting services and corporate finance services, might have an impact on auditor independence.

\subsection{The Effect of Non-Audit Services (NAS) on Auditor Independence}

Current researches (i.e., Abbott, Parker, Peters \& Rama 2003; Weil \& Tannenbaum, 2001; Frankel, Johnson, Nelson, 2002; Nguyen, Ha and Nguyen, 2020) implied that national big companies had a tendency to pay more for NAS, which in turn gave rise to the conflict between auditors supplying audit services and those supplying NAS. For that reason, the study focuses on finding out the link between NAS and auditor objectivity. However, studies related to this relationship reveal many opposite findings as follows:

There are some studies indicating a positive effect of nonaudit services. For example, Jenkins and Krawczyk (2001) showed that the provision of NAS reinforced the belief of 
decision makers about auditor independence. Whisenant, Sankaraguruswamy, and Raghunandan (2003), in the research of valuing the audit and non-audit services, were persuaded of the positive impact of NAS on audit quality after considering the correlation between NAS and audit fee of 2666 observations from the year 2001. This implied that the provision of NAS enhanced auditor objectivity. Similarly, Kinney, Palmrose and Scholz (2004) revealed auditor quality would remain unaffected if audit firms supply consulting services on design and implementation of financial information systems and tax consulting.

There are some studies indicating no effect of non-audit services. Kinney (1999) surveyed empirical studies for over 20 years and found that there was no evidence that auditor independence was affected on auditors' providing NAS at the same time. Wallman (1996) also indicated that the provision of NAS had no clearly negative impact on independence. Palmrose (1999) proved that audit litigation where non-audit services were the basis of lawsuit constituted less than $1 \%$. Different from the research in 1984, Pany and Reckers (1984) in their research analysed the survey that targeted lenders and financial analysts, then drew a conclusion that NAS did not impair auditor independence. Ghosh, Kallapur, \& Moon (2009) claim that there exists no persuasive evidence about the link of auditor independence and auditor fees. RatzingerSakel (2013) also demonstrated that the independence of German auditors was not negatively impacted while providing NAS simultaneously. Chu and Ki (2019) from Auditor's Efforts of Interim Review also provide similar results.

However, most of the previous studies made the conclusion that providing NAS could deteriorate the auditor objectivity.

In the research by Pany and Reckers (1984), the users of financial statements supposedly believed in auditor independence as consulting and auditing were not supplied by the same audit firm. Simunic (1984), Beck, Frecka, and Solomon (1988) voiced the concern that the economic relationship between auditors and clients became stronger when tax and management independence were threatened. However, due to the huge benefit of providing NAS in the context of compromised objectivity, this practice still took place regularly and continuously over time.

Research also indicated that lower auditor independence in audit firms with the parallel provision of non-audit and audit services was mainly due to the fear of losing customers to their competitors. Knapp (1985) sent questionnaires to targeted participants, including reputable lending firms. As a result, respondents showed the firm belief that auditors providing audit services and MAS simultaneously would surrender under pressure from customers and ignore the debts that were not fully recorded in the document. In this case, the independence of auditors was not guaranteed.
Research conducted by Le (2017) revealed that among many non-audit services available in the market, if bookkeeping services and tax advisory services were provided to the same client, auditor independence would be deteriorated.

In addition to management advisory services and taxation services, Law (2010) showed that the provision of internal audit services also influenced auditor independence. The foregoing discussion and rationale leads to the following hypotheses:

H1a. The provision of taxation services to clients would enhance auditor independence.

$\boldsymbol{H} \mathbf{1 b}$. The provision of management advisory services to clients would enhance auditor independence.

H1c. The provision of internal audit services to clients would enhance auditor independence.

Furthermore, NAS fee has an influence on auditor objectivity. Hay, Knechel, and Li (2006) pointed out auditors' acceptance of lower audit fee for more sales and profit from NAS. This implied the adverse relationship, which sequentially alleviates auditor independence.

Wang and Hay (2013) used the data of 99 publicly listed companies on the market to draw a conclusion that the provision of NAS impaired auditor independence. This research model is based on the model of Hay, Knechel \& Li (2006), which considered NAS as dependent variable, NAS fee and auditor decision as independent variables, in order to assess audit fee and NAS fee, relationship between audit fee and auditor's modified decision or level. The result revealed that high NAS fee would lead to a decrease in the auditor's modified decision or level.

Our hypothesis for these discussions is follow:

H2. Non-audit services fees would decrease auditor independence.

\section{Methodology}

\subsection{Research model}

Based on the review of previous studies, the authors proposed the research model as:

$$
\begin{aligned}
A U D I N= & \beta_{0}+\beta_{1} \cdot T A X+\beta_{2} \cdot M A S+\beta_{3} \cdot I N T E R A U D \\
& +\beta_{4} \cdot N A F+\varepsilon
\end{aligned}
$$

In which:

(1) AUDIN: The independence of auditors, is assessed based on the main criterion such as the reliability of the audit opinions as per the users, the accuracy, truthfulness of financial reports, and the objectivity in the opinions of the auditor. 
(2) TAX: It's about providing tax consulting services. Based on Thornton and Shaub (2014) research and results of direct interviews with experts, the observed variables for the variable "Taxation services" include:

- TAX1: Tax strategies designing services

- TAX2: Tax dispute resolution services

- TAX3: Tax declaration services

(3) MAS: The provision of management advisory services. The observed variables used to measure management advisory services variables are built based on the research of Quick and WarmingRasmussen (2005), including:

- MAS1: Management advisory services performed by various individuals within the audit firm

- MAS2 1: Information system designing services

- MAS2_2: Recruitment plan designing services

- MAS2_3: Legal service

- MAS2_4: Accounting-related services

(4) INTERAUD: Outsourcing internal audit service provision, including observed variables determined based on research by Geiger, Lowe and Pany (2002).

- INTERAUD1: Participation of independent auditors in management function of enterprises

- INTERAUD2: Parallel provision of audit and outsourcing internal audit services by one individual in one audit firm

- INTERAUD3: Provision of audit and outsourcing internal audit services by different individuals of different audit firms

(5) NAF: Non-audit service fees. Based on research by Beattie and Fearnley (2002), the authors identified the observed variables including:
- NAF1: Price competition in the market

- NAF2: Non-audit services fee rate

- NAF3: Reputation of audit firms

\subsection{Data Collection}

The research uses the questionnaire based on the Likert scale with five levels from (1 - No effect; 2 - Little effect; 3 - Effect; 4 - Very effective; and 5 - Special effect) with 11 observation variables to test the impact of each NAS on the independence of auditors in Vietnam. The research sent questionnaires to 97 subjects and received 52 valid responses.

\section{Research Results}

\subsection{Descriptive Statistics}

By using the 5-point Likert scale, the authors used descriptive statistics to summarize variables through the mean, median and standard deviations as follows:

\subsection{Cronbach's Alpha Test of Scales}

(i) Cronbach's Alpha test for the variable group "Taxation services": The test result for Cronbach's Alpha coefficient is $0.757>0.6$, a good measurement scale. Although TAX1 has a Cronbach's Alpha if item deleted coefficient is $0.795>0.757$, the difference is 0.038 , which is very small and the correlation coefficient of the total of this observed variable is large, so the authors decided to retain the variable TAX1. Both TAX2 and TAX3 have a Cronbach's Alpha if item deleted coefficient satisfied, as well as Total correlation coefficient $\geq 0.3$.

Table 1: Descriptive Statistics Results

\begin{tabular}{|l|c|c|c|c|}
\hline Groups of variables & Variables & Mean & Median & Standard deviation \\
\hline \multirow{4}{*}{ TAX } & TAX1 & 4.29 & 4.00 & .750 \\
\cline { 2 - 5 } & TAX2 & 4.27 & 4.00 & .689 \\
\cline { 2 - 5 } & TAX3 & 4.15 & 4.00 & .638 \\
\hline \multirow{4}{*}{ MAS } & MAS1 & 3.83 & 4.00 & .648 \\
\cline { 2 - 5 } & MAS2_1 & 4.21 & 4.00 & .572 \\
\cline { 2 - 5 } & MAS2_2 & 3.83 & 4.00 & .678 \\
\cline { 2 - 5 } & MAS2_3 & 4.33 & 4.00 & .785 \\
\cline { 2 - 5 } & MAS2_4 & 4.37 & 4.00 & .715 \\
\hline \multirow{3}{*}{ INTERAUD } & INTERAUD1 & 4.19 & 4.00 & .864 \\
\cline { 2 - 5 } & INTERAUD2 & 4.35 & 4.00 & .711 \\
\cline { 2 - 5 } & INTERAUD3 & 3.92 & 4.00 & .555 \\
\cline { 2 - 5 } & NAF1 & 4.25 & 4.00 & .519 \\
\cline { 2 - 5 } & NAF2 & 4.29 & 4.00 & .772 \\
\cline { 2 - 5 } & NAF3 & 4.13 & 4.00 & .768 \\
\hline
\end{tabular}


(ii) Cronbach's Alpha test for the variable group "Management advisory services": The test result for Cronbach's Alpha coefficient is $0.803>0.6$, a good measurement scale. MAS1 variable has a Cronbach's Alpha coefficient if item deleted is $0.848>0.803$. But the total correlation coefficient is $0.285<0.3$ so this variable should be removed from the scale. The remaining variables: MAS2 1, MAS2_2, MAS2_3 and MAS2_4 all have the total correlation coefficient as well as Cronbach's Alpha coefficient satisfied.

(iii) Cronbach's Alpha test for the variable group "Outsourcing internal audit": The test result for Cronbach's Alpha coefficient is $0.665>0.6$, an acceptable measurement scale. INTERAUD3 variable has a Cronbach's Alpha coefficient if item deleted is $0.709>$ 0.665 but total correlation coefficient is $0.359>0.3$ so the authors decided to retain the variable INTERAUD3. Both INTERAUD1 and INTERAUD2 have satisfactory values.

(iv) Cronbach's Alpha test for the variable group "Nonaudit services fee": The first Cronbach's Alpha test gives a value of $0.588<0.6$ and NAF3 has a Cronbach's Alpha coefficient if item deleted (0.756) is much greater than the Cronbach's Alpha calculated at first, as a result, the scale is unreliable. The authors decided to remove NAF3 variable and do the Cronbach's Alpha test again. This time, the Cronbach's Alpha coefficient is satisfactory $(0.756>0.6)$. Both NAF1 and NAF2 have the acceptable Cronbach's Alpha coefficient if item deleted $(<0.756)$ as well as the total correlation coefficient. The authors decided to retain NAF1 and NAF2 variables to analyse and research. The test results of Cronbach's Alpha scale are reliable for Exploratory Factor Analysis (EFA) which are presented as follows.

\subsection{Exploratory Factor Analysis}

\subsubsection{The First Time of Exploratory Factor Analysis}

$\mathrm{KMO}$ coefficient is $0.715>0.5$, which is satisfactory and factor analysis is appropriate. The Sig value of the Bartlett's test of sphericity test is $0.000<0.05$, so it can be concluded that the factor analysis is significant.

The number of valid questionnaires collected was 52 , so the standard value of the factor loading is 0.5 . However, the Eigenvalue numerical results and the total variance extracted from the EFA analysis results show that a total of 3 factors with Eigenvalue values greater than 1 (which is 1.092) are retained. The total variance extracted is $81.014 \%>50 \%$ so it meets the requirement. Thus, the extracted factors were condensed to $81.014 \%$ of the observed variables and $18.986 \%$ of the observed variables to be lost.
From the rotating results, variable MAS2 1 presented in both Component 1 and Component 2, but the difference between them is $0.019<0.5$. Therefore, the correlation between the observed variable and the generalization factor is unsatisfactory, so the variable MAS2_1 will be removed from the model.

\subsubsection{The Second Time of Exploratory Factor Analysis}

$\mathrm{KMO}$ coefficient is $=0.659>0.5$, satisfactory and factor analysis is appropriate. The Sig value of the Bartlett's test of sphericity is $0.000<0.05$, so it can be concluded that the factor analysis is significant.

The standard value of the factor loading is still 0.5 as during the first time of testing. At this test, the number of factors with Eigenvalue value greater than 1 is still 3 and the total variance extracted is $81.119 \%>50 \%$ which is satisfactory. Factors retained condensed $81.119 \%$ of the observed variables and $18.881 \%$ of the variables lost.

The matrix rotates the observed variables and Factor Loading for the variables as follows:

The variables in this analysis have been divided into 2 groups of factors with factor loading reaching the standard values. Variables are grouped into the following groups:

$\begin{array}{lll}\text { Tax: } & \text { TAX2, TAX3, INTERAUD3 } \\ \text { MAS: } & \text { MAS2_2 } \\ \text { INTERAUD: } & \text { INTERAUD1, MAS2_4, } & \text { MAS2_3, } \\ & \text { TAX1, INTERAUD 2 } \\ \text { NAF: } & \text { NAF1, NAF2 }\end{array}$

Table 2: Matrix Table of $2^{\text {nd }}$ Rotation

\begin{tabular}{|l|c|c|c|c|}
\hline \multirow{2}{*}{} & \multicolumn{4}{|c|}{ Component } \\
\cline { 2 - 5 } & $\mathbf{1}$ & $\mathbf{2}$ & $\mathbf{3}$ & $\mathbf{4}$ \\
\hline INTERAUD1 & .893 & & & \\
\hline MAS2_4 & .805 & & & \\
\hline MAS2_3 & .785 & & & \\
\hline TAX1 & .664 & & & \\
\hline INTERAUD2 & .659 & & & \\
\hline TAX2 & & .951 & & \\
\hline TAX3 & & .773 & & \\
\hline INTERAUD3 & & .560 & & \\
\hline NAF2 & & & .928 & \\
\hline NAF1 & & & .758 & \\
\hline MAS2_2 & & & & .907 \\
\hline
\end{tabular}




\subsection{Pearson Correlation Analysis}

From Cronbach's Alpha test and EFA analysis, the research model consists of 4 independent variables: Taxation services (TAX), Management advisory services (MAS), Outsourcing internal audit services (INNTERAUD) and Non-audit service fee (NAF). In which, TAX variable includes an observation variable INTERAUD 3 added from outsourcing internal audit group. INTERAUD variable is composed of some observation variables, namely MAS 2_3, MAS 2_4 and TAX 1, which are added from the management advisory services group and taxation services group. The value of the independent variables is taken from the average of the observation variables in that factor group.
The Pearson correlation results (Table 3) show that Pearson correlation coefficient between independent variables INTERAUD and AUDIN is 0.292, less than 0.5, thus, there is no chance of strong linear correlation. The results also indicate that the Pearson correlation coefficient between the independent variables is less than 0.5 , the linear correlation is relatively weak, and so there is no possibility of autocorrelation.

\subsection{Regression Analysis}

Results of multivariate regression analysis through running the model by SPSS are summarized in Table 4, 5 and 6 :

Table 3: Pearson Correlation

\begin{tabular}{|c|c|c|c|c|c|c|}
\hline & & TAX & MAS & INTERAUD & NAF & AUDIN \\
\hline \multirow{3}{*}{ TAX } & Pearson Correlation & 1 & $.318^{*}$ & $.486^{* *}$ & $.312^{*}$ & $.467^{* *}$ \\
\hline & Sig. (2-tailed) & & .022 & .000 & .024 & .000 \\
\hline & $N$ & 52 & 52 & 52 & 52 & 52 \\
\hline \multirow{3}{*}{ MAS } & Pearson Correlation & $.318^{*}$ & 1 & $.388^{* *}$ & .114 & $-.281^{*}$ \\
\hline & Sig. (2-tailed) & .022 & & .004 & .423 & .043 \\
\hline & $N$ & 52 & 52 & 52 & 52 & 52 \\
\hline \multirow{3}{*}{ INTERAUD } & Pearson Correlation & $.486^{* *}$ & $.388^{* *}$ & 1 & $.450^{* *}$ & .149 \\
\hline & Sig. (2-tailed) & .000 & .004 & & .001 & .292 \\
\hline & $N$ & 52 & 52 & 52 & 52 & 52 \\
\hline \multirow{3}{*}{ NAF } & Pearson Correlation & $.312^{*}$ & .114 & $.450^{* *}$ & 1 & $.322^{*}$ \\
\hline & Sig. (2-tailed) & .024 & .423 & .001 & & .020 \\
\hline & $N$ & 52 & 52 & 52 & 52 & 52 \\
\hline \multirow{3}{*}{ AUDIN } & Pearson Correlation & $.467^{* *}$ & $-.281^{*}$ & .149 & $.322^{*}$ & 1 \\
\hline & Sig. (2-tailed) & .000 & .043 & .292 & .020 & \\
\hline & $N$ & 52 & 52 & 52 & 52 & 52 \\
\hline
\end{tabular}

*. Correlation is significant at the 0.05 level (2-tailed).

${ }^{* *}$. Correlation is significant at the 0.01 level (2-tailed).

Table 4: $\mathrm{R}^{2}$ Value and Durbin - Watson Value

\begin{tabular}{|c|c|c|c|c|c|}
\hline Model & $\mathbf{R}$ & R Square & Adjusted R Square & $\begin{array}{c}\text { Std. Error of the } \\
\text { Estimate }\end{array}$ & Durbin-Watson \\
\hline 1 & $.651^{\mathrm{a}}$ & .424 & .400 & .30705 & 2.327 \\
\hline
\end{tabular}

a. Predictors: (Constant), MAS, TAX

b. Dependent Variable: AUDIN 
The adjusted $\mathrm{R}^{2}$ coefficient is 0.400 and the $\mathrm{R}^{2}$ coefficient (Table 4) is 0.424 , so the independent variables explain $42.4 \%$ of the dependent variables.

According to the Durbin - Watson coefficient table of Savin and White (1977), with the independent variable of 3 and the number of observed samples is 52 , at the significance level of $0.05, \mathrm{dL}=1.476$ and $\mathrm{dU}=1.635$. The Durbin - Watson coefficient achieved in the model is 2.327 (Table 4), satisfying $\mathrm{dU}<\mathrm{d}<4-\mathrm{dU}$, so no first-order autocorrelation occurs.

The Sig value of the F-test is $0.000<0.05$ (Table 5), the multiple linear regression model is consistent with the data used.

The Sig value of T-test of both independent variables TAX and MAS is $0.000<0.05$ (Table 6), so the above independent variables are all meant to explain the dependent variables and are not excluded from the model. The VIF of all independent variables is less than 2 , so no collinearity occurs.

In conclusion, with 2 initial hypotheses set out from $\mathrm{H} 1$ (H1a, H1b, H1c) and H2, through testing available data, hypothesis $\mathrm{H} 1 \mathrm{c}$ and $\mathrm{H} 2$ are rejected. Therefore, factors related to non-audit services affecting the independence of auditing under this study include: taxation services and management advisory services.

The regression equation is as follows:

$$
A U D I N=3.308+0.473 * T A X-0.279 * M A S
$$

\section{Discussion}

Taxation services are considered as a factor positively affecting the independence of Vietnamese auditors while management advisory services show the inverse trend.

On the plus side, under audit firms' perspective, research results encourage them to increase the frequency of taxation services and limit the supply of management advisory services. This practice can partially help to reinforce auditor independence and then, create more outstanding revenue during their operating period. Under enterprises' opinion, research results are an oriented base that help to guarantee the true and fair view in their financial statements and take a step towards suitable taxation and managerial strategy. Under the government's view in general management, research results provide a reference channel contributing to law enactment for the transparency of macro economy.

On the minus side, with the limitation in number of participants, independent variables and observation variables, research results cannot reflect all aspects related to the impact of non-audit services on the auditor independence in Vietnam. To be specific, after data processing, the regression equation only includes a modest 2 independent variables, namely, taxation services (coefficient of 0.473 ) and management advisory services (coefficient of -0.279).

Table 5: F-Test results for suitability of the regression model ANOVA ${ }^{a}$

\begin{tabular}{|l|c|c|c|c|c|}
\hline Model & Sum of Squares & Df & Mean Square & F & Sig. \\
\hline Regression & 3.395 & 2 & 1.697 & 18.004 & $.000^{\mathrm{b}}$ \\
\hline Residual & 4.620 & 49 & .094 & & \\
\hline Total & 8.014 & 51 & & & \\
\hline
\end{tabular}

a. Dependent Variable: AUDIN

b. Predictors: (Constant), MAS, TAX

Table 6: $\beta$ Value, T-test and VIF Magnification Factor

\begin{tabular}{|l|c|c|c|c|c|c|c|}
\hline \multirow{2}{*}{ Model } & \multicolumn{2}{|c|}{$\begin{array}{c}\text { Unstandardized } \\
\text { Coefficients }\end{array}$} & $\begin{array}{c}\text { Standardized } \\
\text { Coefficients }\end{array}$ & \multirow{2}{*}{$\mathbf{t}$} & \multirow{2}{*}{ Sig. } & \multicolumn{2}{|c|}{ Collinearity Statistics } \\
\cline { 2 - 4 } \cline { 6 - 8 } & $\mathbf{B}$ & Std. Error & Beta & & & Tolerance & VIF \\
\hline (Constant) & 3.308 & .372 & & 8.903 & .000 & & \\
\hline TAX & .473 & .087 & .619 & 5.411 & .000 & .899 & 1.112 \\
\hline MAS & -.279 & .067 & -.478 & -4.179 & .000 & .899 & 1.112 \\
\hline
\end{tabular}

a. Dependent Variable: AUDIN 
Compared to research of Quick and WarmingRasmussen (2005) in the Denmark economy, our findings in the Vietnamese market reinforce the theory that the more management advisory services are provided, the more auditor independence is impaired.

Moreover, our research gives the evidence for the positive impact of supplying taxation services on auditor independence in Vietnam and the same trend is also found in research of Law (2010) in Hong Kong. When compared to findings of Le (2017) with the same research environment, which shows taxation services deteriorate auditor independence, our research results show the converse, paving the way for another perspective on this relationship.

\section{Conclusion}

All suggested above, taxation services and management advisory services show an opposite impact on the independence of the auditor. Therefore, by increasing the supply of taxation services and decreasing the provision of management advisory services, the independence of the auditor will be guaranteed and enhanced at a remarkable rate.

There are many ways to maintain the auditor independence in supplying NAS, one of which is to enhance the quality of NAS, i.e., taxation services. Firstly, human resources in auditing are highly recommended to improve in both quantity and quality with a view to creating more added value for the consulted enterprises. This practice can indirectly mitigate the negative effect of non-audit services to the auditor independence. Besides, technological advances are highly encouraged to avoid mistakes for the transparency of each stage of non-audit services.

In conclusion, the research has pointed out the relationship between the non-audit services and the independence of the auditor, according to which there are two factors directly affecting auditor objectivity, namely taxation services and management advisory services. The results can be considered as new findings of our research compared to previous researches in Vietnam, which in turn create a new viewpoint about the relationship between the NAS and the independence of the auditor. Beside the success, our research has some limitations, one of which is the restriction in independent variables. In fact, there are many NAS elements affecting the auditor objectivity, such as risk assurance and corporate finance services. The reason for the shortage of these above services is that they are not common in Vietnamese market in the period that the survey was conducted.

\section{References}

Abbott, L. J., Parker, S., Peters, G. F., \& Rama, D. V. (2003). Audit, nonaudit, and information technology fees: Some empirical evidence. Accounting and the Public Interest, 3(1), 1-20. https://doi.org/10.2308/api.2003.3.1.1

AICPA (1997a). Codification of auditing standards - SAS No. I, AICPA Professional Standards, New York.

AICPA (1997b). Serving the Public Interest: A New Conceptual Framework for Auditor Independence. New York.

Bartlett, R. W. (1993). A scale of perceived independence: New evidence on an old concept. Accounting, Auditing \& Accountability Journal, 6(2). https://doi. org/10.1108/09513579310036378

Beattie, V., \& Fearnley, S. (2002). Auditor Independence and NonAudit Services: A Literature Review. Institute of Chartered Accountants in England and Wales, London.

Beattie, V., Brandt, R., \& Fearnley, S. (1999). Perceptions of auditor independence: UK evidence. Journal of International Accounting, Auditing and Taxation, 8(1), 67-107. https://doi. org/10.1016/S1061-9518(99)00005-1

Beck, P. J., Frecka, T. J., \& Solomon, I. (1988). An empirical analysis of the relationship between MAS involvement and auditor tenure: Implications for auditor independence. Journal of Accounting literature, 7(1), 65-84.

Blay, A. D., \& Geiger, M. A. (2013). Auditor fees and auditor independence: Evidence from going concern reporting decisions. Contemporary Accounting Research, 30(2), 579-606. https://doi.org/10.2139/ssrn.1943124

Brandon, D. M., Crabtree, A. D., \& Maher, J. J. (2004). Nonaudit fees, auditor independence, and bond ratings. Auditing: A Journal of Practice \& Theory, 23(2), 89-103. https://doi. org/10.2308/aud.2004.23.2.89

Chu, J., \& Ki, E. S. (2019). Do auditor's efforts of interim review curb the analyst forecast's walkdown? Journal of Asian Finance, Economics and Business, 6(2), 45-54. https://doi. org/10.13106/jafeb.2019.vol6.no2.45

Dopuch, N., King, R. R., \& Schwartz, R. (2003). Independence in appearance and in fact: An experimental investigation. Contemporary Accounting Research, 20(1), 79-114. https://doi.org/10.1506/9B5D-HLLP-BBQE-8N3F

Eilifsen, A., Messier, W. F., Glover, S. M., \& Prawitt, D. F. (2013). Auditing and assurance services. New York, NY: McGraw-Hill.

Firth, M. (1997). The provision of nonaudit services by accounting firms to their audit clients. Contemporary Accounting Research, 14(2), 1-21. https://doi. org/10.1111/j.1911-3846.1997.tb00524.x

Frankel, R. M., Johnson, M. F., \& Nelson, K. K. (2002). The relation between auditors' fees for nonaudit services and earnings management. The accounting review, 77(s-1), 71-105. https://doi.org/10.2308/accr.2002.77.s-1.71

FRC. (2010). Revisions to FRC guidance on audit committees: Non-audit services. Retrieved October 26, 2020 from https:// www.accaglobal.com/vn/en/technical-activities/technicalresources-search/2010/october/frc-revisions.html 
Ghosh, A. A., Kallapur, S., \& Moon, D. (2009). Audit and non-audit fees and capital market perceptions of auditor independence. Journal of Accounting and Public Policy, 28(5), 369-385. https://doi.org/10.1016/j.jaccpubpol.2009.07.001

Geiger, M. A., Lowe, D. J., \& Pany, K. J. (2002). Appearances are important: Outsourced internal audit services and the perception of auditor independence. The CPA Journal, 72(4), 20-25.

Habib, A., \& Islam, A. (2007). Determinants and consequences of non-audit service fees. Managerial Auditing Journal, 22(5), 446-469. https://doi.org/10.1108/02686900710750748

Hay, D., Knechel, R., \& Li, V. (2006). Non-audit services and auditor independence: New Zealand evidence. Journal of Business Finance \& Accounting, 33(5-6), 715-734. https://doi. org/10.2139/ssrn.452260

Jenkins, J. G., \& Krawczyk, K. (2001). The influence of nonaudit services on perceptions of auditor independence. Journal of Applied Business Research, 17(3). https://doi.org/10.19030/ jabr.v17i3.2235

Kinney Jr, W. R. (1999). Auditor independence: A burdensome constraint or core value?. Accounting Horizons, 13(1), 69. https://doi.org/10.2308/acch.1999.13.1.69

Kinney Jr, W. R., Palmrose, Z. V., \& Scholz, S. (2004). Auditor independence, non-audit services, and restatements: Was the US government right? Journal of Accounting Research, 42(3), 561-588. https://doi.org/10.1111/j.1475-679X.2004.t011-00141.x

Knapp, M. C. (1985). Audit conflict: An empirical study of the perceived ability of auditors to resist management pressure. Accounting Review, 202-211.

Kwak, J. W., \& Park, M. J. (2020). Effect of auditor's simultaneous audit and tax services and tax-service fee on firm value: Korea's evidence. Journal of Asian Finance, Economics and Business, 7(7), 219-228. https://doi.org/10.13106/jafeb.2020. vol7.no7.219

Law, P. (2010). The influence of the types of NAS provisions and gifts hospitality on auditor independence. International Journal of Accounting \& Information Management, 105-117. https:// doi.org/10.13106/10.1108/18347641011048101

Le, D. D. M. (2017). Non-audit services and independence of Vietnamese auditors. Financial Review, 1(6), 80-83.

Nguyen, H. A., Ha, H. H., \& Nguyen, L. S. (2020). Determinants of Information Technology Audit Quality: Evidence from Vietnam. Journal of Asian Finance, Economics and
Business, 7(4), 41- 50. https://doi.org/10.13106/jafeb.2020. vol7.no4.41

Palmrose, Z. V. (1999). Empirical research in auditor litigation: Considerations and data. American Accounting Association.

Pany, K., \& Reckers, P. M. (1984). Non-audit services and auditor independence-A continuing problem. Auditing: A Journal of Practice \& Theory, 3(2), 89-97.

Quick, R., \& Warming-Rasmussen, B. (2005). The impact of MAS on perceived auditor independence-some evidence from Denmark. Accounting Forum, 29(2), 137-168. https://doi. org/10.1016/j.accfor.2004.09.001

Ratzinger-Sakel, N. V. (2013). Auditor fees and auditor independence-Evidence from going concern reporting decisions in Germany. Auditing: A Journal of Practice \& Theory, 32(4), 129-168. https://doi.org/10.2308/ajpt-50532

Savin, N. E., \& White, K. J. (1977). The Durbin-Watson test for serial correlation with extreme sample sizes or many regressors. Econometrica: Journal of the Econometric Society, 1989-1996.

Simunic, D. A. (1984). Auditing, consulting, and auditor independence. Journal of Accounting Research, 679-702. https://doi.org/10.2307/2490671

SEC. (2000). Final Rule: Revision of the Commission's Auditor Independence Requirements. November, 21, 2000. Retrieved October 26, 2020 from https:/www.sec.gov/rules/ final/33-7919.htm

Thornton, J. M., \& Shaub, M. K. (2014). Tax services, consequence severity, and jurors' assessment of auditor liability. Managerial Auditing Journal, 29(1), 50-75.

Wallman, S. M. H. (1996). The future of accounting, part III: Reliability and auditor independence, Accounting Horizons, 10, 76-97.

Wang, S. W. S., \& Hay, D. (2013). Auditor independence in New Zealand: Further evidence on the role of non-audit services. Accounting and Management Information Systems, 12(2), 235-262. https://doi.org/10.2139/SSRN.2218072

Weil, J., \& Tannenbaum, J. (2001). Big companies pay audit firms more for other services. Wall Street Journal, 10. Retrieved October 26, 2020 from https://www.wsj.com/articles/ SB986848130788136961

Whisenant, S., Sankaraguruswamy, S., \& Raghunandan, K. (2003). Evidence on the joint determination of audit and non-audit fees. Journal of Accounting Research, 41(4), 721-744. https:// doi.org/10.1111/1475-679X.00121 